\title{
FINANCING LOWER-SECONDARY SCHOOLS FROM THE EUROPEAN UNION FUNDS AND THE SCHOOL EDUCATION SYSTEM REFORM IN POLAND
}

\author{
IWONA KOWALSKA
}

Warsaw University of Life Sciences - SGGW, Faculty of Economic Sciences, POLAND

e-mail: iwona_kowalska@sggw.pl

RECEIVED
ACCEPTED
JEL
CLASSIFICATION

KEYWORDS

ABSTRACT

\author{
18 January 2018 \\ 2 September 2018 \\ $\mathrm{G} 28, \mathrm{H} 52, \mathrm{H} 75$
}

finance, UE, lower-secondary school, repayment, reform, education

\begin{abstract}
The reform of the school education system in Poland launched during the 2014-2020 programming period may have consequences for the absorption of EU funds due to the planned phasing out of lower-secondary schools. This issue deserves consideration with regard to the efficiency and rationality of allocation of EU funds in the area of public policy of an EU Member State. The purpose of this article is to investigate the following questions: 1) What is the potential risk of the EU authorities demanding repayment of EU funds allocated to lower-secondary schools due to their phasing-out?; 2) Is it admissible to apply for EU funds by lower-secondary schools during the phasing-out period? The applied method included review of documents regarding legal conditions in the two periods of EU programming in Poland, i.e. years 2007-2013 and 2014-2020, as well as the review of literature on local self-governments' finance sector. The conducted analyzes refer to the official statement issued by the Ministry of Development regarding the research questions addressed in this paper. The study concludes that there are indicators that repayment of EU funds already awarded to lower secondary schools may be demanded and the admissibility of application for EU funding for these schools during phasing out period may further increase the financial burden on local self-governments in communes.
\end{abstract}

\section{Introduction}

Economic and political integration within the European Union (EU) creates the need to regulate the relationship between the Union's political and law system and the equivalent systems of individual member states (see Nuzzo, 2015, p. 172). Poland's membership in the European Union and the simultaneous lack of membership in the monetary and economic union significantly affect Polish finance law and the actual functioning of the state 
within the applicable finance law of Poland and the European Union (Kosikowski, 2014, p. 15). An example of the lack of synchronization between the EU finance system and the finance system of Poland seems to be the case of school education system reform, which involves phasing-out of lower-secondary schools - the beneficiaries of EU funds. The implementation of this reform during the 2014-2020 programming period may have consequences for the absorption of EU funds. This issue deserves consideration as every Member State is required to respect the provisions of Art. 71 of General Regulation No. 1303/2013 and Art. 57 of General Regulation No. 1083/2006. The articles provide that an operation retains the contribution from the Funds only if that operation does not, within five years from the completion of the operation, undergo a substantial modification affecting its nature or its implementation conditions. Despite the importance of these provisions, in Polish literature on the subject there is no analysis of the possible risk of the demand of repayment of EU funds resulting from the implementation of new public policy. Previous studies in this field mainly addressed the following issues:

1. Barriers in application for EU funding by local self-governments (reports of Province Job Centres, pp. 4-5).

2. Efficiency in absorbing EU funds with the use of macroeconomic models (i. a. Tracz-Krupa, 2015, p. 341).

3. Effectiveness of EU support (i. a. reports of the Ministry of Infrastructure and Development, 2014).

4. Comprehensive analyses of the EU budget (i. a. publications of the European Commission: European Union public finance; Financial Regulation applicable to the general budget of the Union and its rules of application).

Another inspiration to address this issue was the standpoint of the Ministry of Development (MD) obtained under public inquiry in 2017. According to the Ministry the liquidation of lower-secondary schools does not automatically imply the loss of EU funding for projects implemented by these schools. The commitments resulting from the need to preserve the sustainability of the EU funded operations will be transferred to other actors (schools, educational institutions, and governing bodies) within the framework of legal succession, provided that the operations' intended objectives continue to be implemented and the educational functions of infrastructure co-financed by EU funds are maintained. Furthermore, the changes resulting from the reform of the school education system do not impose the obligation to stop allocating EU funding to lower-secondary schools. With regard to the abovementioned approach, the objective of this article is to investigate the following questions:

1. What is the potential risk of the EU authorities demanding repayment of EU funds allocated to lowersecondary schools due to their phasing-out?

2. Is it admissible to apply for EU funds by lower-secondary schools during the phasing-out period?

\section{Method}

Taking into account the research questions and the time of writing this paper, (preceding the period of phasingout lower-secondary schools under the Education Act of 14 December 2016 and Regulations introducing the Education Act), the applied method included review of documents regarding legal conditions of the two periods of EU programming in Poland, i.e. years 2007-2013 and 2014-2020, as well as the review of literature on local self-governments' finance sector. 


\section{The risk of recovery of EU funds allocated to lower-secondary schools with regard to the statement of the Ministry of Development}

The statement of the Ministry of Development is controversial. Bearing in mind the requirement of sustainability of operation results, in the case of phasing-out of lower-secondary schools the following scenarios may unfold:

1. If the lower-secondary schools are not transformed into a different type of school, it would be appropriate to expect the EU decision to recover allocated funds. It is on condition that the effect of lower-secondary school projects is shorter than the required period of five years after the last payment from EU funds to a school.

2. If the lower-secondary schools are transformed into a different type of schools, there are still indicators that a decision to recover EU funds can be taken. It is because the description of the results will not be consistent with the new type of school setting. The applicants for EU funds for lower-secondary schools were obliged to describe of each element of the project with regard to the specificity of this stage of education and that included: justification of the project implementation; formulation of the objectives of the project; identification of the target group; description of the project tasks; risk assessment; added value of the project, the management team and the project budget.

The consequence of failure to preserve the sustainability of the project is the need to repay EU funds allocated in accordance with the instructions contained in art. $207 \mathrm{sec}$. 1 of the Public Finance Act of 27 August 2009 (hereinafter referred to as PFA). This provision implies that in the case where funding allocated to the implementation of programs co-financed by European funds are:

- misused,

- used in breach of the procedures referred to in art. 184 PFA,

- acquired illegally or in excessive amount,

the unduly amount is subject to repayment by the beneficiary together with interest at the rate determined for tax arrears, calculated from the date of transfer of funds, within 14 days from the date of delivery of the decision to return the funds to the bank account indicated in the decision. Funds incorrectly spent become public funds constituting non-taxable budget receivables of public and legal character.

The procedure for recovering EU funds is of an administrative nature. The authority acting as the Managing Authority (MA) / Intermediate Body (IB) issues a decision specifying the amount to be repaid, the date from which interest is charged and the method of repayment. In cases regarding receivables not regulated by PFA, the provisions of the Code of Administrative Proceedings (hereinafter referred to as CAP) or Section III of the Tax Ordinance Act (hereinafter referred to as TOA) shall apply. It is worth to devote attention to the amount to be returned. According to article 207 section 9 of the PFA - the authority (...) issues a decision determining the amount to be repaid. The amount to be repaid is therefore determined in the decision by an authority that is not bound by any regulations. The upper limit for the amount to be repaid is the amount of funding provided to the beneficiary. When estimating the amount to be repaid, it is important to note that payments and subsidies are given in separate tranches and may be transferred to the beneficiary on different dates. In such cases, the amount to be repaid should be the sum of the separately calculated amounts: for payments and for subsidies. The decision should also specify the method of repayment - deduction of another payment or return to a bank account (see Rogowski, 2011, pp. 6-12). 
The appeal procedure against the decision regarding the recovery of funds is regulated in art. 127 of the CAP and following articles (Chapter 10, Section II) with art. 67 of the PFA. However, the authority is not bound by the findings of the audit - it is possible to provide evidence against the content of the documents (results, minutes, inspection reports). On the other hand, according to art. 66 of the PFA the enforcement of claims is regulated by the Act of 17 June 1966 on enforcement proceedings in administration. It is should be noted here that, as for the legal forms securing recovery of unduly payments, the executing authority may only initiate administrative enforcement on the basis of an enforceable title (Pismo DKR-VII-8261 (0) - 46-MWi / 11, pp. 1-2).

Furthermore, there are doubts concerning the concept of legal succession proposed by the Ministry of Development. Succession is a transfer of a legal title that results in a legal succession relationship between the previous holder of the title and the acquirer. The opposite of a succession which involves a derivative acquisition (Wolter, 1972, p. 121) is a primary acquisition, where the legal title is not transferred from an individual who formerly held it (it does not depend on the fact that the right was previously vested with a particular entity) (Radwański, 2009, p. 100). Derivative acquisition may take place under the general title (universal succession) or the detailed title (singular succession). None of these legal constructs is intended to transfer the sustainability of the lowersecondary school project results. In the case of universal succession (acquisition of all property rights on the basis of a single legal act) it is possible only in the cases specified in the law (e.g. inheritance, acquisition of inheritance, transformations of commercial companies or merger of legal entities). Essential standards for universal succession are laid down in:

- Commercial Companies Code (articles 494 and 531),

- Tax Ordinance Act (articles from 93 to 107),

- Civil Code (article 922).

In turn, examples of singular succession (the purchase of a single, individually designated right from the seller) is e.g.: sale, exchange, donation of specific items, payment of a sum of money from the bank account to the person named in the agreement after the death of the holder of this account.

It should be emphasised that the repayment of EU funds transferred to lower-secondary schools will burden communes (their governing bodies) with the obligation to indicate the source of coverage of the amount due. If it is decided to provide the needed funds from external sources, the individual debt ratio (IDR) should be taken into account. The amount of debt limit for local self-governments is regulated by art. 243 of the PFA. The IDR system makes the planned amount of liabilities (debt) dependent on the ability to repay those obligations. Creditworthiness is calculated by taking into account the financial surplus, in accordance with the formula for limiting the repayment of liabilities as defined in that provision:

$$
\left(\frac{R+0}{D}\right)_{n} \leq \frac{1}{3} \times\left(\frac{D b_{n-1}+S m_{n-1}-W b_{n-1}}{D_{n-1}}+\frac{D b_{n-2}+S m_{n-2}-W b_{n-2}}{D_{n-2}}+\frac{D b_{n-3}+S m_{n-3}-W b_{n-3}}{D_{n-3}}\right),
$$

where:

$R$ - Planned for the fiscal year total amount due for the repayment of loan and credit instalments and redemption of securities - payments to debt incurred to maintain liquidity and repaid by the end of the financial year are not included in the expenditure on this account,

0 - Planned for the financial year interest on loans and interest and discount on issued securities as well as repayment resulting from the granted sureties and guarantees, 
$D$ - Total budget income for the financial year,

$D b$ - Current income,

$\mathrm{S} m$ - Asset sale gains,

$W b$ - Current expenditure,

$n$ - Financial year for which the relation is determined,

$n-1$ - Year prior to the financial year for which the relation is determined,

$n-2$ - Year two years prior to the financial year,

$n-3$ - Year three years prior to the financial year.

The analysis of data from Multiannual Financial Perspective (Wieloletnia Prognoza Finansowa - WPF) aggregated from the reports on meeting obligations - a statutory instrument of control and monitoring debt (in force from 2014) - showed that in the years 2015-2018, hundreds of local self-governments will be unfit to incur new debt obligations in the form of loans, credits and securities. When formulating such opinions Regional Chambers of Audit (Regionalne Izby Obrachunkowe - RIO) take into account the methodology of Multiannual Financial Perspective developed by the Ministry of Finance according to which the key assumption made in the development of this document should be how much money a local self-governments have and not how much they need (Soltyk, Dębowska-Sołtyk, 2016, p. 95). Exceeding IDR results in local government's inability to adopt the commune's budget. Consequently, the necessity to repay EU funds transferred to lower-secondary schools may require local governments to make significant adjustments in budget planning.

There is one more potential consequence of the recovery of EU funds transferred to lower-secondary schools. If the repayment of EU funds is not possible without exceeding the IDR, the local self-governments in communes may be interested in using non-standard debt instruments, i.e. commitments in the form of loan or credit agreements, although not included in the debt portfolio of the public debt. This category of instruments includes: equity financing, return sale, leaseback, instalment payment, subrogation (Kluza, 2015, p. 61). Their use is permitted by the Regulation of the Minister of Finance of 28 December 2011 concerning the detailed method of classification of debt instruments classified as public debt, but in the opinion of the Regional Chambers of Audit it is necessary to amend the statutory debt portfolio by including unnamed agreements with effects similar to loan or credit agreement. This is due to the fact that the calculations of Regional Chambers of Audit (Niestandardowe... 2016, pp. 23-31) show that there is a group of local governments that have been at risk of losing liquidity or have lost liquidity following the use of these financial instruments.

\section{Applying for EU funds for lower-secondary schools during their phasing out with regard to the statement of the Ministry of Development}

The opinion of the Ministry of Development quoted in the introduction raises doubts in at least three substantive areas:

1. Does not the acquisition of EU funds to support lower secondary schools during the 2-year phasing out period, (i.e. a period shorter than the required 5-year sustainability of the project effects), increase the risk of potential burdening communes with the financial commitments in the programming period 20142020 (Operational Program Knowledge Development Education - POWER / 16 Regional Operational Programs - ROP)? While in the programming period 2007-2013 the acquisition of EU funds for lower 
secondary schools took place within legal framework securing the stability of school education system, during the implementation period of the EU programming 2014-2020 there was a change of legislation defining precisely the period in which lower-secondary schools will be phased out (1.09.2017-31.08.2019). Therefore, the application for EU funds for lower-secondary schools at the time of their phasing out implies that the Managing Authority's (MA) grants consent for communes' actions, which may result in the repayment of EU funds due to the lack of sustainability of project products.

2. What will be the effect of EU funding provided for lower secondary schools (investment in teachers, students, equipment, etc.)? There are two exemplary scenarios which can be explored: 1) the situation when the project effects cannot be used in the sector of public education services; 2 ) the situation when the received EU support will be inadequate due to the radical change in the functioning of schools in public education sector during and after the phasing-out of lower secondary schools. In the first case the illustration may be a situation of teaches who received professional training co-financed by EU funds, e.g. physical education teachers, who when dismissed from lower-secondary schools will look for a job outside the education system (e.g. in fitness sector). In the second case, the illustration may be the situation of lower-secondary school teachers trained in developing learners' key competencies who will be unable to implement their abilities in the new situation of being a 'touring" teacher' forced to work part time in a number of different schools.

3. What would be the financial impact for communes repaying EU funds transferred to lower-secondary schools in the 2014-2020 programming period if the state's education policy changed and school education system with lower-secondary schools was restored? Would communes be able to demand compensation for the recovered EU funds in the situation of restoring lower-secondary schools?

\section{Conclusions}

The conducted analyses show that there are indicators that repayment of EU funds already transferred to lowersecondary schools may be demanded and the admissibility of application for EU funding for these schools during phasing-out period may further increase the risk of increasing the financial pressure on local self-governments in communes. The conceptual approach outlined in this paper would require further research. The necessary actions which should be taken in the discussed area include:

1. Creating an interdisciplinary research team to estimate the amount of EU funds recovery for Poland as well as ex ante economic effectiveness (identifying and estimating expected effects, inputs and time) and ex post economic effectiveness (dealing with the outcomes of specific actions, i.e. real effects and input) (Penc, 1997, pp. 99-100).

2. Developing a financial support system for communes obliged to repay EU funds if the condition of sustainability of project results was not met due to statutory changes in the school education system in Poland.

3. Developing a communication strategy for Poland in the dialogue with decision-making bodies representing the EU regarding the possible recovery of allocated EU funds. This strategy should be part of the preparation of the Polish side to negotiate another EU budget under conditions of the likely concept of flexible integration (see Barcz, 2015, pp. 252 et seq.). 


\section{References}

Act of 14 December 2016 Education Act. Journal of Laws in 2017, item 59.

Act of 14 December 2016 Regulations introducing the Education Act. Journal of Laws in 2017, item 60.

Act of 14 June 1960 Code of Administrative Proceedings. Journal of Laws in 2017, item 1257.

Act of 15 September 2000 Commercial Companies Code. Journal of Laws in 2016, item 1578, 1579, 2255, 2260 and 2017 item 791 , $1089,1133$.

Act of 23 April 1964 Civil Code. Journal of Laws in 2017, item 459, 933, 1132.

Act of 27 August 2009 Public Finance. Journal of Laws in 2016, item 1870, 1948, 1984, 2260 and 2017, item 60, 191, 659, 933, 935, 1089.

Act of 29 August 1997 Tax Ordinance. Journal of Laws in 2017, item 201, 648, 768, 935.

Act on enforcement proceedings in administration of 17 June 1966. Journal of Laws in 2016, item 599, 868, 1228, 1244, 1579, 1860 , 1948, and 2017, item. 933.

Badanie skuteczności wsparcia realizowanego w ramach komponentu regionalnego PO KL 2007-2013 (2014). Raport Ministerstwa Infrastruktury i Rozwoju, Warszawa.

Barcz, J. (2015). Główne kierunki reformy ustrojowej post-lizbońskiej Unii Europejskiej. Piaseczno: Wyd. Wszechnica IJM.

Bariery w aplikowaniu o środki z EFS przez Jednostki Samorządu Terytorialnego (2009). Raport końcowy. WUP w Poznaniu, Poznań.

Council Regulation (EC) No. 1083/2006 of 11 July 2006 laying down general provisions on the European Regional Development Fund, the European Social Fund and the Cohesion Fund and repealing Regulation (EC) No. 1260/1999. Official Journal of the European Union L 210/25.

European Union public finance (2014). Directorate-General for Budget, Brussels.

Financial Regulation applicable to the general budget of the Union and its rules of application (2017). European Union, Luxembourg.

Kluza, K. (2015). Innowacje finansowe w jednostkach samorządu terytorialnego na skutek wejścia w życie art. 243 ustawy o finansach publicznych. Studia Ekonomiczne. Zeszyty Naukowe Uniwersytetu Ekonomicznego w Katowicach, 238, 53-64.

Kosikowski, C. (2014). Finanse i prawo finansowe Unii Europejskiej. Warszawa Wolters Kluwer.

Niestandardowe instrumenty finansowania potrzeb budżetowych jednostek samorządu terytorialnego (2016). Krajowa Rada Regionalnych Izb Obrachunkowych, Łódź.

Nuzzo, B. (2015). Państwa członkowskie Unii Europejskiej: nowy paradygmat suwerenności? Zarys problemu. Świat Idei i Polityki, 14, 169-186.

Penc, J. (1997). Leksykon biznesu. Warszawa: Placet.

Pismo Dyrektora Departamentu Koordynacji i Wdrażania Programów Regionalnych w Ministerstwie Rozwoju Regionalnego z dnia 12.09.2011. DKR-VII-8261(0)-46-MWi/11)

Radwański, Z. (2009). Prawo cywilne - część ogólna. Warszawa: C.H. Beck.

Regulation (EU) No. 1303/2013 of the European Parliament and of the Council of 17 December 2013 establishing common rules for the European Regional Development Fund, the European Social Fund, the Cohesion Fund, the European Agricultural Fund for Rural Development and the European Maritime and Fisheries Fund; laying down general provisions on the European Regional Development Fund, the European Social Fund, the Cohesion Fund, the European Agricultural Fund for Rural Development and the European Maritime and Fisheries Fund and repealing Council Regulation (EC) No. 1083/2006. Official Journal of the European Union L374 / 320.

Regulation of the Minister of Finance of 28 December 2011 concerning the detailed method of classification of debt instruments classified as public debt. Journal of Laws in 2011, no. 298, item 1767 with amendments.

Rogowski, A. (2011). Analiza prawna dla Ministerstwa Rozwoju Regionalnego dotycząca procedury dochodzenia zwrotu środków UE Programu Operacyjnego Infrastruktura i Środowisko, na podstawie art. 207 ustawy z dnia 27 sierpnia 2009 r. o finansach publicznych. Warszawa.

Sołtyk, P., Dębowska-Sołtyk, M. (2016). Finanse samorządowe. Warszawa: Difin. 
Tracz-Krupa, K. (2015). Efektywność a skuteczność wykorzystania środków Programu Operacyjnego Kapitał Ludzki w perspektywie 2007-2013 w Polsce. Prace Naukowe Uniwersytetu Ekonomicznego we Wrocławiu, 386, 329-342.

Wolter, A. (1972). Prawo cywilne, Zarys części ogólnej. Warszawa: PWN.

Cite this article aS: Kowalska, I. (2018). Financing lower-secondary schools from the European Union Funds and the school education system reform in Poland. European Journal of Service Management, 3 (27/2), 221-228. DOI: 10.18276/ejsm.2018.27/2-27. 